\title{
頭蓋咽頭腫に対する通常分割高精度放射線外部照射療法の長期成績
}

\author{
溝脇 尚志 ${ }^{1)}$, 小倉 健吾1), 坂中 克行 ${ }^{1)}$, 宇藤 恵 $^{1)}$, 荒川 芳輝 ${ }^{2}$, 北条 雅人 ${ }^{2) 3}$, \\ 宮本 享 ${ }^{2}$, 平岡 真寛 ${ }^{1)}$ \\ 1）京都大学大学院医学研究科放射線腫瘍学・画像応用治療学, 2) 京都大学大学院医学研究科脳神経外科学, 3) 滋賀県立成人 \\ 病センター脳神経外科
}

\section{Long-term Outcomes of Conventionally-fractionated High-precision Radiotherapy for Craniopharyngioma}

\author{
Takashi Mizowaki, M.D., Ph.D. ${ }^{1)}$, Kengo Ogura, M.D., Ph.D. ${ }^{1)}$, Katsuyuki Sakanaka, M.D., Ph.D. ${ }^{1)}$, \\ Megumi Uto, M.D. ${ }^{1)}$, Yoshiki Arakawa, M.D., Ph.D. ${ }^{2)}$, Masato Hojo, M.D., Ph.D. ${ }^{2) 3}$, \\ Susumu Miyamoto, M.D., Ph.D. ${ }^{2)}$, and Masahiro Hiraoka, M.D., Ph.D. ${ }^{1)}$
}

1) Department of Radiation Oncology and Image-Applied Therapy, Kyoto University, Graduate School of Medicine, 2) Department of Neurosurgery, Kyoto University, Graduate School of Medicine, 3) Department of Neurosurgery, Shiga Medical Center for Adults

Although craniopharyngiomas are categorized as benign brain tumors, long-term prognoses have not been satisfactory due to their locational difficulties and invasiveness. Conventinally-fractionated radiation therapy is the standard radiotherapeutic approach for residual or recurrent diseases after surgery, which significantly improves not only local progression-free rates but also survival outcomes. However, longterm results for patients treated with modern high-precision radiotherapy techniques have not been sufficiently reported. In this retrospective study, 5-year outcomes of Japanese patients with residual or recurrent craniopharyngioma treated with high-precision radiotherapy were evaluated.

A total of 29 patients with residual or recurrent craniopharyngioma, who were consecutively treated with three-dimensional conformal radiation therapy or streotactic radiation therapy between January 2001 and September 2012, were included in the analyses. The median age was 54 years old (range: 7-78). Five pediatric cases (median: 9 years old, range: 7-15) were included. The number of prior surgeries before radiation therapy was one in 18 cases, two in 9 cases and three in 2 cases. Incomplete resection was performed on 28 cases in the most recent surgery before radiation therapy, while gross total resection was achieved in only one patient. Some sort of pituitary hormone deficiency was observed in 28 (97\%) cases before radiation therapy. The clinical target volume (CTV) was created by adding a $0-5 \mathrm{~mm}$ margin to the tumor bed. The planning target volume was generated by adding a $3-10 \mathrm{~mm}$ margin to the CTV. The median prescribed dose at the isocenter was $54 \mathrm{~Gy}$ (range : 50.4-54) in a fraction size of $1.8 \mathrm{~Gy}$.

The median follow-up period after radiotherapy was 73 months (range:27-191). Local recurrence was observed in 5 cases and ectopic intracranial recurrence was observed in one patient. Five-year local control, progression-free survival and overall survival rates were $85.3 \%$ (95\% confidence interval [CI] : 65.1, 94.2), 81.4\% (95\% CI:60.7, 93.4) and 95.8\% (95\% CI:73.9, 99.4), respectively. No radiation-induced acute toxicity was observed. In one patient, thyroid stimulating hormone replacement treatment was required 67 months after radiation therapy. No other instances of radiation-related late toxicity were observed.

High-precision radiation therapy in conventional fractionation could achieve a favorable long-term tumor control rate with minimum complications in Japanese patients with residual or recurrent craniopharyngioma. This approach should therefore be considered as the first-choice option in managing residual or

連絡先：溝脇尚志，广 606-8507 京都市左京区聖護院川原町 54 京都大学医学部附属病院放射線治療科

Address reprint requests to: Takashi Mizowaki, M.D., Ph.D., Department of Radiotherapy, Kyoto University Hospital, 54 Shogoinkawahara-cho, Sakyo-ku, Kyoto-shi, Kyoto 606-8507, Japan 
recurrent craniopharyngioma after surgery.

(Received January 15, 2016 ; accepted February 15, 2016)

Key words : craniopharyngioma, high-precision external-beam radiation therapy, stereotactic radiation therapy, conventional fractionation

Jpn J Neurosurg（Tokyo） $25: 646^{-653, ~} 2016$

\section{緒 言}

頭蓋咽頭腫はまれな良性脳腫瘍の 1 つであり，外科的 完全摘出（gross total resection：GTR）で治癒が期待でき る疾患である。完全摘出できた場合の 10 年生存率は $80 \%$ 程度と良好な成績が報告されている(17)25)。しかし ながら，主な発生部位が鞍上部であり，脳下垂体や視交 叉等のリスク臟器が近接して存在すること, しばしば周

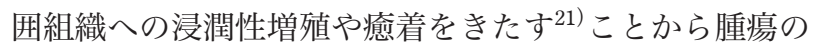
GTR は容易ではない，また，GTRできても，下垂体視 床下部症状を中心とした重篤な有害事象のリスクも大き くなることが問題点である115)1317)。一方，不完全切除 （imcomplete resection：ICR）に終わった場合は，追加治 療を行わなければ 10 年生存率は $50 \%$ 程度に低下してし まう ${ }^{1)}$ 。これに対して，ICR 例の残存腫瘍と腫瘍床に術 後放射線治療を施行すると, GTR 群とほぼ同等の生存率 が期待可能である ${ }^{82025)}$.

標準的な放射線治療方法は, 1 回 1.8〜 2 Gy の通常分割 照射による残存腫瘍または腫瘍床への術後照射であ $3^{2224)}$. 旧来の二次元放射線治療に代わって近年臨床現 場に急速に普及した三次元原体照射（three-dimensional conformal radiotherapy: 3D-CRT), 強度変調放射線治療 (intensity-modulated radiation therapy：IMRT)，および定 位放射線治療（stereotactic radiation therapy：SRT）など の高精度放射線外部照射療法によって良好な長期成績が 報告されている49)15). しかし，いまだ経過観察期間中央 值 5 年以上の報告は少なく, 特に国内からのまとまった 報告はほとんどみられないのが現状である.

本研究では, 京都大学において通常分割照射による 3D-CRT またはSRT で加療した頭蓋咽頭腫の長期成績を 検討した.

\section{方法・症例}

本解析は, 京都大学大学院医学研究科・医学部および 医学部附属病院医の倫理委員会の承認を得て実施した （承認番号：E2277）.
Table 1 Patient characteristics

\begin{tabular}{l|c}
\hline & Value \\
\hline Male/female & $14 / 15$ \\
Adult/child & $24 / 5$ \\
Age at RT, median (range) & $54(7-78)$ \\
Number of prior surgery & \\
$\quad$ Once & 18 \\
$\quad$ Twice & 9 \\
$\quad$ Thrice & 2 \\
Extent of the immediate surgery & \\
$\quad$ GTR & 5 \\
$\quad$ STR & 23 \\
PR & \\
Tumor type & 17 \\
$\quad$ Cystic & 4 \\
$\quad$ Solid & 8 \\
Mixed & 10 \\
HRT at RT & 18 \\
$\quad$ Anterior alone & 1 \\
$\quad$ Anterior + posterior & 15 \\
No & \\
Dysfunction of visual function & \\
\hline RT : radiotherapy, GTR : gross total resection, \\
STR : subtotal resection, PR : partial resec- \\
tion, HRT : hormone replacement therapy
\end{tabular}

\section{1 対象}

2000 年 1 月 2012 年 9 月に京都大学医学部附属病院 に打いて，通常分割高精度外部放射線療法で連続して加 療された頭蓋咽頭腫 29 例（男性：14，女性：15）を解析 対象とした。年齢中央值は 54 歳（7〜 78 歳）で，小児 5 名（7 15 歳, 中央值: 9 歳), 成人 24 名（19 78 歳, 中央值：58 歳）であった。初発時から放射線治療までの 腫瘍切除術の施行回数は, 1 回が 18 例, 2 回が 9 例, 3 回が 2 例であった（当初より 2 期的切除を計画のうえ行 われた一連の手術は 1 回とカウント)。放射線治療施行直 前の手術内容は, GTR, 亜全摘術（subtotal resection： STR, 腫瘍体積 10\%未満残存), 部分切除（partial resection：PR，腫瘍体積 $10 \%$ 以上残存）はそれぞれ 1 例， 5 例, 23 例であった。過去に何らかの放射線治療歴がある 患者はいなかった。

全例において，手術検体の病理組織学的評価で頭蓋咽 
Table 2 Summary of radiation therapy

\begin{tabular}{ll|r}
\hline & & Value \\
\hline RT technique & 3D-CRT & 12 \\
& SRT & 17 \\
Dose/fractions & $54 \mathrm{~Gy} / 30$ & 16 \\
& $52.2 \mathrm{~Gy} / 29$ & 10 \\
Mean dose (Gy) & $50.4 \mathrm{~Gy} / 28$ & 3 \\
Median dose (Gy) & & 53 \\
PTV coverage (\% iso-dose line) & & 54 \\
& 3D-CRT & $95 \%$ \\
& SRT & $90 \%$ \\
\hline
\end{tabular}

$\mathrm{RT}$ : radiotherapy, 3D-CRT : three-dimensional conformal radiation therapy, SRT : stereotactic radiation therapy, PTV : planning target volume

頭腫との確定診断が得られていた。腫瘍性状は，囊胞型 (囊胞成分が全体の $50 \%$ 以上) : 17 例, 充実型（囊胞成分 が認めら机ないか全体の $10 \%$ 未満) $: 4$ 例, 混合型（囊胞 成分が全体の 10〜 50\%):8例であった。放射線治療開始 時点で, ホルモン補充を要する下垂体前葉機能障害を 28 例（97\%）に認めた。このうち 18 例（62\%）は，前葉機 能に加えて後葉機能低下を伴う汎下垂体機能障害の状態 であり，抗利尿ホルモンの補充も必要であった。1 15 例 （51\%）において，放射線治療前に視機能異常を認めた。 患者背景のまとめを Table 1 に示す.

\section{2 患者固定法}

放射線治療における患者固定には，非侵襲性の頭頝部 用固定マスク (Klarity Medical Products, Ohio, USA) に バイトブロックを追加したものを用い，仰臥位で加療し た。高齢等の理由によってバイトブロックが使用困難な 例は，マスクシステムのみを用いて加療した。

\section{3 放射線治療}

放射線治療の施行夕イミングは，直前の腫瘍切除術後 に引き続いてアジュバント療法として施行： 12 例, 初回 または 2 回目術後に腫瘍の再増大を認めたため救済手術 を施行した後にアジュバント療法として施行：10 例，初 回術後に腫瘍の再増大を認めたため救済放射線治療とし て施行： 7 例であった。再発時に急速な増大で神経症状 を伴うものは再手術アアジュバント放射線治療，緩徐な 増大で神経症状を伴わない場合は放射線治療単独での救 済が行われることが多かった。

治療計画の概要を Table 2 に示す。 2006 年までは, CadPlan（ver. 6.2.7）または Eclipse（ver. 7.1.35）（Varian
Medical Systems，Palo Alto，CA，USA）を用いて治療計 画を立案し，Clinac 2100C または 2300C/D（Varian Medical Systems）を用いて加療を行った。2007 年以降は, BrainScan またはiPlan（BrainLAB AG，Feldkirchen, Germany）を用いて治療計画を行い，NOVALIS（BrainLAB AG）を用いて加療した.

臨床標的体積（clinical target volume：CTV）は残存腫 瘍を含む腫瘍床とし，2007 年以降は，術前に腫瘍と接し ていた正常脳実質 $5 \mathrm{~mm}$ を CTV に含めた. CTVに $3 \sim 10$ $\mathrm{mm}$ のマージンを付与して計画標的体積 (planning target volume：PTV）を作成した。したがって，視交叉，脳下 垂体は多くの症例で PTV 内に含まれた。

放射線照射法については，2006 年までは，コプラナー ビーム配置の 3D-CRT (回転原体照射を含む)で加療し， 2007 年以降は，非コプラナー配置を含む $3 \sim 4$ アークの 回転原体照射（通常分割 SRT）で加療した。PTV は， 3D-CRT では処方線量の 95\%, SRT では 90\%等線量曲 線でカバーされるように治療計画を立案した。

投与線量は，アイソセンター処方で 50.4〜 $54 \mathrm{~Gy} / 28$

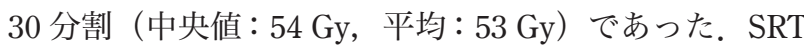
プラン立案に際しては，X線が眼球を通過しないように ベッド回転角度を調整した。また，通過ビームが体幹部 に達せず肩口から抜けるように水平および $45 \sim 50$ 度の 4 アークを用い，生殖器を含む体幹部の被曝線量を最小限 とするように努めた。

\section{4 経過観察と評価方法}

放射線治療後は, 脳神経外科医または放射線治療医が 経過観察を行い，おおよそ半年〜 1 年ごとに MRI 検査を 施行した。 MRI 検査では, $\mathrm{T} 1$ および $\mathrm{T} 2$ 強調画像の水平 および冠状断像に加えて原則として造影検査も施行され た。一部の症例では，CT 検査が合わせて施行された。 また，小児および AYA（adolescent and young adult）世代 の患者を中心に，必要に応じて内分泌代謝内科医も定期 的な経過観察および投薬を行った。

本研究においては，各種画像検査所見を遡及的に見直 し，放射線治療後の経過観察 MRI または CT 画像上，固 形成分，囊胞成分にかかわらず腫瘍の増大所見が認めら れた時点で局所再発と判定した．腫瘍サイズが不変，縮 小および消失維持の場合を局所制御と判定した。すなわ ち，放射線治療後に腫瘍が縮小したが，少し増大したも のの治療時のサイズまで達しない場合も，再増大を確認 した時点で局所再発の判定とした。異所性再発は，画像 上確認された時点を再発日とした。 

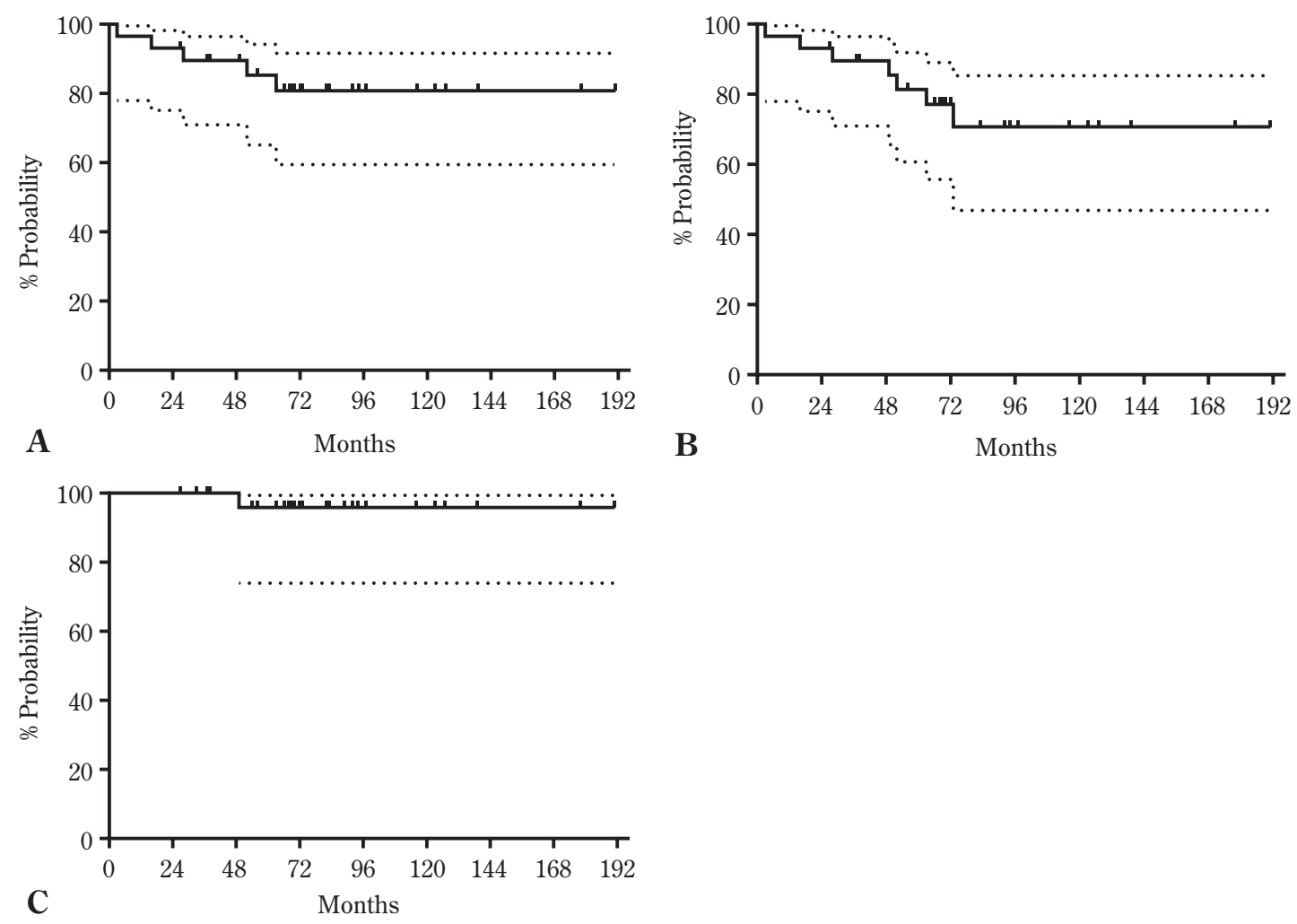

Fig. 1 Kaplan-Meier plots with 95\% confidence interval of local control (A) ; progression-free survival (B); and overall survival rates $(C)$.

\section{5 統計解析}

局所制御率，無増悪生存率，全生存率は，いずれも放 射線治療終了日を起点として Kaplan-Meier 法を用いて 推定した。統計解析には, GraphPad Prism（ver. 5.04, GraphPad Software Inc., La Jolla，CA，USA）を使用した.

\section{結 果}

経過観察期間中央值は 73 力月（範囲：27～191 力月） であった．局所再発を 5 例に, 頭蓋内の異所性（脳梁） 再発を別の 1 例に認めた。局所再発をきたした 5 例は, いずれも ICR 後にアジュバント治療として放射線治療を 行った例であった。他病死した 1 例を除き, 最終確認時 点において全例生存中であった. 5 年の局所制御率，無 増悪生存率，全生存率は，それぞれ，85.3\%（95\%信頼 区間：65.1，94.2)，81.4\% (60.7，93.4)，95.8\%（73.9, 99.4）であった（Fig. 1).

宿酔・脱毛などの放射線治療に起因すると考えられた 急性期症状は観察されなかった。 3 例において, 放射線 治療後視機能の悪化をきたしたが, 2 例は局所再発， 1 例 は頭蓋内出血が原因であり, 放射線性視神経炎が原因と
判断されるものは認められなかった。

小児の 4 例において，成長ホルモン製剤および女性ホ ルモン製剤，成人男性の 2 例においては，男性ホルモン 製剤の投与が新たに開始された。これらのホルモン補充 療法は，放射線治療前より当該ホルモン值が低值であっ たため夕イミングを見計らって開始されたものであり, 放射線治療との関連性はないと判断された。他の成人の 1 例では，放射線治療後に甲状腺刺激ホルモン值の低下 をきたし，放射線治療後 5 年 7 力月の時点からレボチロ キシンナトリウムの投与が開始され，放射線治療の晚期 有害事象と考えられた。脳壊死等，他の晚期有害事象は 観察されていない.

1 例では放射線治療中から交通性水頭症で歩行障害を きたし，放射線治療後にシャント術が施行された。また， 別の 1 例では, 腫瘍切除術翌日にくも膜下出血をきたし, 続発した水頭症のため V-Pシャント術が施行された。本 例では，脳血管に異常所見を認めず，腫瘍の切除断端部 からの出血と判断された.

典型的な治療経過の 1 例を Fig. 2 に示す。初発時 7 歳 の女児で，鞍上部中心に巨大な囊胞性腫瘍を認め，周囲 の正常構造物の著明な圧排を認めた（Fig. 2A）。初回手 

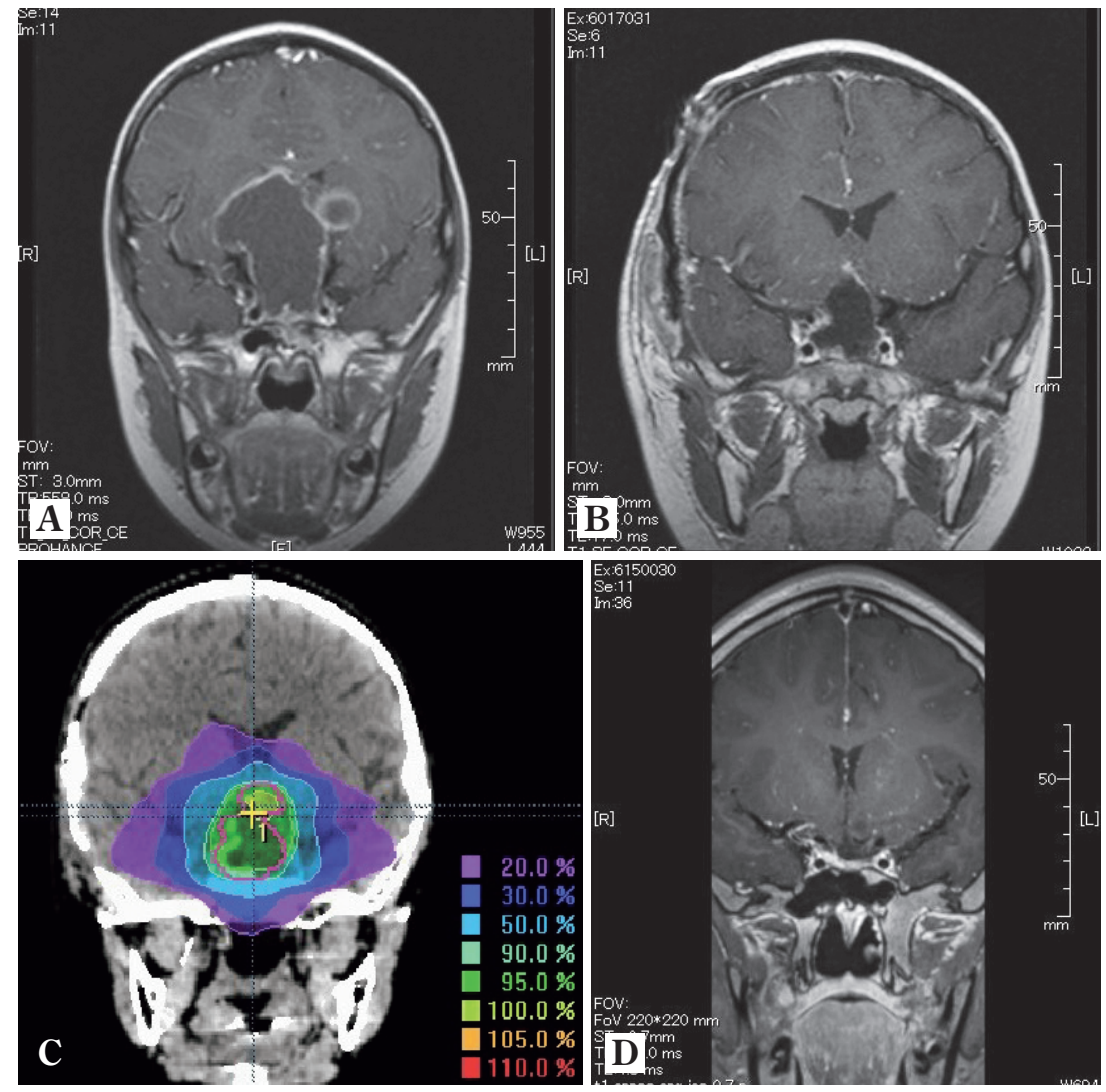

Fig. 2 A : T1-weighted contrast enhanced magnetic resonance imaging (MRI) at the initial diagnosis.

B : T1-weighted contrast enhanced MRI after the 2nd surgery and just before the radiation therapy.

C : Dose distribution of the treatment plan created on the BrainScan treatment planning software.

D : T1-weighted contrast enhanced MRI obtained 88 months after the stereotactic radiation therapy.

術 (STR) 後 1 カ月で急速な再増大を認め, 再手術 (STR) 後に放射線治療目的で紹介された (Fig. 2B). NOVALIS を用いた通常分割 SRT により $54 \mathrm{~Gy} / 30$ 回が残存腫瘍お よび腫瘍床へ投与され (Fig. 2C), 放射線治療後 88 力月 の時点で再発や有害事象を認めず経過観察継続中である (Fig. 2D).

\section{考 察}

頭蓋咽頭腫は組織学的には良性の腫瘍であるものの浸 潤性であることが珍しくなく ${ }^{21)}$ ，視交叉や脳下垂体など のリスク臓器が密集する鞍上部に発生するため, GTR は 容易ではない，そのため，GTRにより治癒が期待できる ものの，GTRを目指すと重篤な有害事象のリスクが有意 に高まるため ICRに留めざるを得ない場合がしばしば経 験される1)513)17).
初回手術が ICR や生検に留まった症例においては, 当 然ながら再手術によるコントロール率は高くはなく，10 年生存率は $50 \%$ 未満と報告されている ${ }^{1111)}$ 。一方, ICR や生検後の残存腫瘍に対して通常分割での放射線治療を 行うと, 10 年の局所制御率, 生存率ともに $80 \%$ 程度と全 摘術後と同等の治療成績が得られる311116). Clark ら $^{3)}$ は, 主として通常分割照射で加療された 104 の報告からの系 統的レビューの結果，5年の非進行生存率は, GTR 例, ICR+放射線治療例でそれぞれ $77 \%, 73 \%(\mathrm{p}=0.76)$ と 同等であったと報告している。一方，ICR+放射線治療 と ICR 単独の比較では，それぞれ $73 \%, 43 \%(\mathrm{p}=0.003)$ と ICR+放射線治療が有意に良好であった。

さらに有害事象に関しては, ICR+放射線治療と比較 して GTRは，少なくとも1つのホルモン異常をきたすリ スクが 2.5 倍 ${ }^{23)}$ ，尿崩症をきたすリスクが 7.7 倍 ${ }^{2}$ 高いと 報告されている。実際，あえてGTRを目指さず有害事象 
Table 3 Recently-reported outcomes of radiotherapy for craniopharyngioma using modern techniques with $\geq 5^{-}$year follow-up period

\begin{tabular}{|c|c|c|c|c|c|c|c|}
\hline $\begin{array}{l}\text { Author } \\
\text { (Year) }\end{array}$ & Equipment & $\begin{array}{c}\text { Median } \\
\text { dose }(G y) / f r\end{array}$ & No. of cases & $\begin{array}{c}\text { Median } \\
\mathrm{f} / \mathrm{u} \text { (months) }\end{array}$ & $\begin{array}{c}5 \text { (10)-year } \\
\text { LC }(\%)\end{array}$ & $\begin{array}{l}5 \text { (10)-year } \\
\text { PFS }(\%)\end{array}$ & $\begin{array}{c}5 \text { (10)-year } \\
\text { OS }(\%)\end{array}$ \\
\hline $\begin{array}{c}\text { Moon }^{16)} \\
(2005)\end{array}$ & LA & $54 / 30$ & 50 & 130 & - & $\begin{array}{c}95 \\
(91)\end{array}$ & $\begin{array}{c}96 \\
(91)\end{array}$ \\
\hline $\begin{array}{c}\text { Combs }^{4)} \\
(2007)\end{array}$ & LA & $52.2 / 29$ & 40 & 98 & $\begin{array}{c}100 \\
(100)\end{array}$ & - & $\begin{array}{c}97 \\
(89)\end{array}$ \\
\hline $\begin{array}{c}\text { Harrabi }{ }^{9)} \\
(2014)\end{array}$ & LA & $52.2 / 29$ & 55 & 128 & $\begin{array}{c}95 \\
(92)\end{array}$ & - & $\begin{array}{c}90 \\
(83)\end{array}$ \\
\hline $\begin{array}{l}\mathrm{Lo}^{12)} \\
(2014)\end{array}$ & LA & $50.4 / 28$ & 48 & 107 & - & $\begin{array}{c}93 \\
(82)\end{array}$ & $\begin{array}{c}90 \\
(80)\end{array}$ \\
\hline $\begin{array}{c}\text { Mizowaki } \\
\text { (This study) }\end{array}$ & LA & $54 / 30$ & 29 & 73 & 85 & 81 & 96 \\
\hline $\begin{array}{l}\text { Hasegawa }^{10)} \\
\quad(2010)\end{array}$ & GK & $11.4 / 1$ & 109 & 68 & 69 & 62 & 93 \\
\hline $\begin{array}{l}\text { Niranjan }^{18)} \\
\quad(2010)\end{array}$ & GK & $13 / 1$ & 46 & $62^{*}$ & 68 & - & 97 \\
\hline $\begin{array}{c}\text { Yomo }^{26)} \\
(2015)\end{array}$ & GK & $12 / 1$ & 51 & 71 & 67 & 63 & 92 \\
\hline
\end{tabular}

LC : local control rate, PFS : progression-free survival rate, OS : overall survival rate, LA : linear accerelator, GK : gamma knife, * Mean follow-up time

のリスクを最小に抑えたミニマム手術後にアジュバント 放射線治療を行う治療方針で，77\%の10 年生存率が得 られている20).

以上のことから，術後残存腫瘍に対する通常分割放射 線治療は標準的な放射線治療方法と位置付けられてお り ${ }^{2224)}$ ，今後は当初から術後の通常分割放射線治療の併 用を前提とした有害事象のリスクを最大限回避した手術 アプローチの重要性が増してくるものと予想される。な お，放射線治療施行の夕イミングとして，手術後のア ジュバント治療として施行された報告が多いが，再増大 時点で施行する場合との優劣については明らかではない。

古典的な二次元照射による通常分割照射の場合，局所 線量が 55 Gy 以上の場合に有意に治療成績が良好である と報告されている ${ }^{8)}$ 。一方，視神経の耐容線量は 50〜 54 $\mathrm{Gy}$ 程度とされており7), 実際に $54 \mathrm{~Gy} / 30$ 分割 (50 Gy/25 分割相当）までの線量では，放射線性神経炎による視力 低下はほとんど報告されておらず，著者らの経験上も安 全な線量と考えられる。治療後の生活の質がより重視さ れる現代においては，耐容線量が低い小児例や小児と同 様に長期予後が期待できる AYA 世代例も多く含まれる こともあり，放射線性視神経炎による失明リスクが増加 するとされる $55 \mathrm{~Gy}$ 以上の投与を避ける傾向となってい る。このような中，近年の 3D-CRT，IMRT および SRT などの高精度放射線外部照射法で加療された場合, 総線 量 50.4 54 Gy で良好な長期成績が報告されてい
$3^{9) 12) 16)}$ (Table 3).

現在，術後残存または再発腫瘍に対する通常分割照射 以外の放射線治療オプションとしては，主としてガンマ ナイフを用いて施行される定位手術的照射（stereotactic radiosurgery：SRS）や直線加速器による少分割 SRT が挙 げられる。これらの中で大部分を占めるガンマナイフに ついては, 10 年成績は報告されていないものの, $90 \%$ 以 上の良好な 5 年全生存率が得られている ${ }^{1018) 26)}$ 。一方, 5 年無増悪生存率については, 評価基準が一律でないた め単純な比較が困難ではあるものの，80〜90\%の通常分 割照射と比較してSRSは 60\%程度に留まるため ${ }^{1018) 26)}$, 通常分割照射の成績が良好である（Table 3)。この理由 は，通常分割照射の場合， $54 \mathrm{~Gy}$ までは視交叉を含めて 腫瘍床や残存腫瘍を安全に照射可能であるのに対し，1 回照射である SRS では，PTV 辺縁で 11〜13 Gy，中心で 22〜26 Gy 以上を投与する一方で視交叉の耐容線量が 8〜12 Gy 程度に留まるため ${ }^{19)}$, 腫瘍辺縁部の実効線量が 低いうえに視交叉近くの腫瘍や腫瘍床を十分含んで加療 できないことが原因と推測される。いったん SRSによっ て視交叉へ耐容線量近い照射を行うと, 近傍に辺緑再発 をきたした場合に再度の根治的放射線治療が困難となる ことが多く, 10〜20 年の長期でみると生存率の低下につ ながることが予想される。したがって，初回治療として の SRS の適用には慎重を要すると考えられる.

従来の標準的なターゲット設定は，残存腫瘍に $10 \mathrm{~mm}$ 
のマージンを加えて CTV とし，CTVに $5 \mathrm{~mm}$ のマージ ンを加えて PTV とする方法である ${ }^{24)}$. 現在われわれは, CTV として, 残存腫瘍および術前の腫瘍存在部位に加え て腫瘍と接していた正常脳実質 $5 \mathrm{~mm}$ とし，3〜 $5 \mathrm{~mm}$ の PTV マージンを加えて 54 Gy を処方している. Merchant $ら^{14)}$ は，CTV マージンを $5 \mathrm{~mm}, \mathrm{PTV} マ$ マ ジンを $3 \mathrm{~mm}$ まで縮小したが， 5 年無増悪生存率の低下は認められな かったと報告している。ささなる長期観察が必須である ものの, 照射範囲の縮小とそれに伴う晚期有害事象発生 リスク軽減の可能性が示唆されている.

通常分割照射は腫瘍床をはじめ再発リスクの高い範囲 を十分含めて加療可能である一方，下垂体は通常照射野 内に含まれるため, SRS と比較して内分泌異常をきたす リスクが高いことが短所である。もつとも，頭蓋咽頭腫 では，放射線治療開始時点において原疾患と手術のため にすでに汎下垂体機能低下をきたしている症例も少なく ないため, 下垂体機能が保たれている例が多い下垂体腺 腫と比較して, 晚期障害としての下垂体機能低下が問題 となる場合は少ない，自験例においても，放射線治療の 晚期有害事象と考元られる新たな下垂体機能障害は, 甲 状腺刺激ホルモン低下をきたした 1 例のみであった。 以 上のことから, 下垂体機能が保たれており, 視交叉など のリスク臓器に近接していない残存・再発例が, 下垂体 機能温存を目的として SRS の適用を積極的に考慮すべ き対象と考えられる。ただし，局所制御の失敗は長期的 には生存率の低下につながるリスクが高いため, 局所制 御率を犠牲にしても内分泌機能温存を優先する妥当性は 見出しがたく, 対象症例の選択には慎重を要する.

旧来の二次元照射による通常分割放射線治療で加療し た場合, 晚期有害事象として神経認知機能の低下が報告 されている ${ }^{16)}$.しかしながら, 通常分割 SRTで加療した 40 例中 38 例では, 経過観察期間中央值 98 力月で, まっ たく神経認知機能低下を認めなかったと報告されてい る ${ }^{4)}$. また, 別の研究においても, 3D-CRTで加療され た場合放射線治療後も有意な神経認知機能低下は観察さ れず6), 最近の 3D-CRT, IMRT やSRT を用いた $54 \mathrm{~Gy}$ ま での通常分割照射では，放射線による晚期有害事象のリ スクはきわめて低いと考えられる。

以上のように, 高精度放射線外部照射療法による通常 分割照射は, 現時点において, 術後残存/再発頭蓋咽頭腫 に対して第 1 選択とされるべき放射線治療方法であると 考元られる。本研究は, 遡及的検討であるという制限は あるものの, 術後残存/再発頭蓋咽頭腫に対する通常分 割照射の長期の有効性と安全性を, わが国の症例を通し て提示できた意義は大きいと考えられる.
謝 辞

本論文内容の発表および執筆において, 貴重な機会を賜り ました札幌医科大学脳神経外科の三國信啓教授に心より感謝 申し上げます。

\section{利益相反 (COI) 開示}

すべての著者は, 本論文の内容に関して開示すべき COI は ありません。

\section{文 献}

1) Caldarelli M, Massimi L, Tamburrini G, Cappa M, Di Rocco $\mathrm{C}$ : Long-term results of the surgical treatment of craniopharyngioma: the experience at the Policlinico Gemelli, Catholic University, Rome. Childs Nerv Syst 21: 747-757, 2005.

2) Clark AJ, Cage TA, Aranda D, Parsa AT, Auguste KI, Gupta $\mathrm{N}$ : Treatment-related morbidity and the management of pediatric craniopharyngioma : a systematic review. J Neurosurg Pediatr 10: 293-301, 2012.

3) Clark AJ, Cage TA, Aranda D, Parsa AT, Sun PP, Auguste KI, Gupta N : A systematic review of the results of surgery and radiotherapy on tumor control for pediatric craniopharyngioma. Childs Nerv Syst 29 : 231-238, 2013.

4) Combs SE, Thilmann C, Huber PE, Hoess A, Debus J, Schulz-Ertner D : Achievement of long-term local control in patients with craniopharyngiomas using high precision stereotactic radiotherapy. Cancer 109:2308-2314, 2007.

5) Crowley RK, Hamnvik OP, O'Sullivan EP, Behan LA, Smith D, Agha A, Thompson CJ: Morbidity and mortality in patients with craniopharyngioma after surgery. Clin Endocrinol (Oxf) 73: 516-521, 2010.

6) Di Pinto M, Conklin HM, Li C, Merchant TE : Learning and memory following conformal radiation therapy for pediatric craniopharyngioma and low-grade glioma. Int J Radiat Oncol Biol Phys 84: e363-369, 2012.

7) Emami B, Lyman J, Brown A, Coia L, Goitein M, Munzenrider JE, Shank B, Solin LJ, Wesson M : Tolerance of normal tissue to therapeutic irradiation. Int J Radiat Oncol Biol Phys 21: 109-122, 1991.

8) Habrand JL, Ganry O, Couanet D, Rouxel V, Levy-Piedbois C, Pierre-Kahn A, Kalifa C: The role of radiation therapy in the management of craniopharyngioma : a 25-year experience and review of the literature. Int J Radiat Oncol Biol Phys 44:255-263, 1999.

9) Harrabi SB, Adeberg S, Welzel T, Rieken S, Habermehl D, Debus J, Combs SE : Long term results after fractionated stereotactic radiotherapy (FSRT) in patients with craniopharyngioma: maximal tumor control with minimal side effects. Radiat oncol $9: 203,2014$.

10) Hasegawa T, Kobayashi T, Kida $Y$ : Tolerance of the optic apparatus in single-fraction irradiation using stereotactic radiosurgery : evaluation in 100 patients with craniopharyngioma. Neurosurgery 66 : 688-694; disucussion 694-685, 2010.

11) Kalapurakal JA, Goldman S, Hsieh YC, Tomita T, Marymont $\mathrm{MH}$ : Clinical outcome in children with recurrent craniopharyngioma after primary surgery. Cancer J $\quad \mathbf{6}: 388-393$, 2000.

12) Lo AC, Howard AF, Nichol A, Sidhu K, Abdulsatar F, Hasan $\mathrm{H}$, Goddard $\mathrm{K}$ : Long-term outcomes and complications in patients with craniopharyngioma: the British Columbia 
Cancer Agency experience. Int J Radiat Oncol Biol Phys 88: 1011-1018, 2014.

13) Merchant TE, Kiehna EN, Sanford RA, Mulhern RK, Thompson SJ, Wilson MW, Lustig RH, Kun LE : Craniopharyngioma : the St. Jude Children's Research Hospital experience 1984-2001. Int J Radiat Oncol Biol Phys 53:533$542,2002$.

14) Merchant TE, Kun LE, Hua CH, Wu S, Xiong X, Sanford RA, Boop FA : Disease control after reduced volume conformal and intensity modulated radiation therapy for childhood craniopharyngioma. Int J Radiat Oncol Biol Phys 85 : e187192, 2013.

15) Minniti G, Saran F, Traish D, Soomal R, Sardell S, Gonsalves A, Ashley S, Warrington J, Burke K, Mosleh-Shirazi A, Brada $\mathrm{M}$ : Fractionated stereotactic conformal radiotherapy following conservative surgery in the control of craniopharyngiomas. Radiother Oncol 82: 90-95, 2007.

16) Moon SH, Kim IH, Park SW, Kim I, Hong S, Park CI, Wang $\mathrm{KC}$, Cho BK: Early adjuvant radiotherapy toward long-term survival and better quality of life for craniopharyngiomas - a study in single institute. Childs Nerv Syst 21:799-807, 2005.

17) Mortini P, Losa M, Pozzobon G, Barzaghi R, Riva M, Acerno $\mathrm{S}$, Angius D, Weber G, Chiumello G, Giovanelli M : Neurosurgical treatment of craniopharyngioma in adults and children : early and long-term results in a large case series. $J$ Neurosurg 114: 1350-1359, 2011.

18) Niranjan A, Kano H, Mathieu D, Kondziolka D, Flickinger JC, Lunsford LD : Radiosurgery for craniopharyngioma. Int J Radiat Oncol Biol Phys 78: 71, 2010.

19) Pollock BE, Link MJ, Leavitt JA, Stafford SL : Dose-volume analysis of radiation-induced optic neuropathy after single- fraction stereotactic radiosurgery. Neurosurgery $\quad \mathbf{7 5}: 456^{-}$ 460 ; discussion 460, 2014.

20) Rajan B, Ashley S, Gorman C, Jose CC, Horwich A, Bloom HJ, Marsh H, Brada M : Craniopharyngioma-a long-term results following limited surgery and radiotherapy. Radiother Oncol 26:1-10, 1993.

21) Russell DS, Rubinstein LJ : Craniopharyngeoma and suprasellar epidermoid cysts. in Eussel DS, Rubinstein LJ (eds) : Pathology of Tumors of the Nervous System, 5th Edtition. London, Edward Arnold, 1989, pp.695-702.

22) Shrieve D, Wagner AE : Craniopharyngioma. in Gaffney DK, Shrieve D, Anker CJ, Buyyounouski MK, Kong FM, Hitchcock YJ, Tward JD (eds) : Radiation Oncology Imaging and Treatment. Altona, Amirsys Publishing, 2013, pp.22-23.

23) Sughrue ME, Yang I, Kane AJ, Fang S, Clark AJ, Aranda D, Barani IJ, Parsa AT : Endocrinologic, neurologic, and visual morbidity after treatment for craniopharyngioma. J Neurooncol 101: 463-476, 2011.

24) Winkfield KM, Bazan JG, Gibbs IC, Eng TY, C. R. T : Craniopharingeoma in Nonmalignant diseases (Chapter 91). in Halperin EC, Wazer DE, Perez CA, Brady LW (eds) : Perez and Brady's Principles and Practice of Radiation Oncology, Sixth Edition. Philadelphia, Lippencott Williams \& Wilkins, 2011, pp.1733-1736.

25) Yang I, Sughrue ME, Rutkowski MJ, Kaur R, Ivan ME, Aranda D, Barani IJ, Parsa AT : Craniopharyngioma : a comparison of tumor control with various treatment strategies. Neurosurg Focus 28: E5, 2010.

26) Yomo S, Konishi Y, Motohiro H : Long-term treatment results of Gamma Kife stereotactic radiosurgery for craniopharyngeoma. Jpn J Neurosurg 24 : 533-543, 2015.

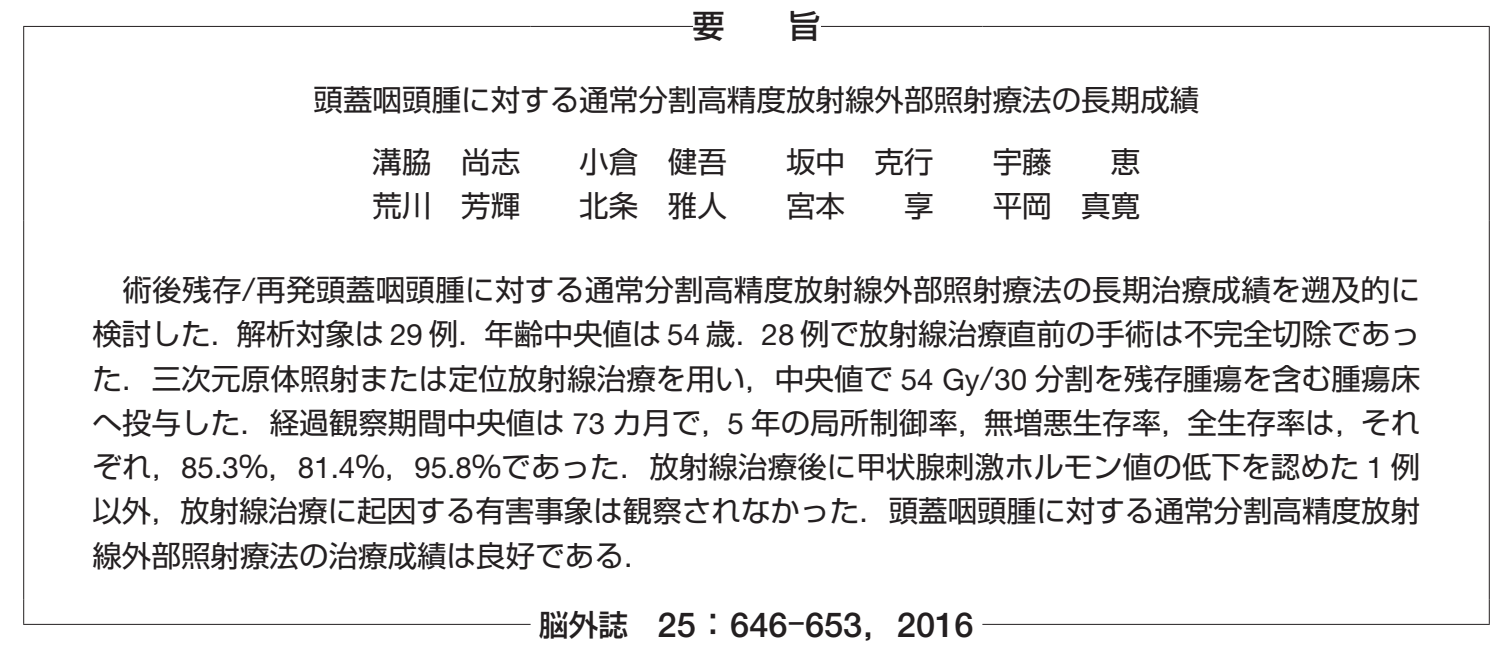

